\title{
Standing on Unsteady Ground: AREVA NP Incorporated in France $v$ Eskom SOC LTD
}

\section{H van Eetveldt*}

\section{P.E.R}

Pioneer in peer-reviewed, open access online law publications

Author

Henri-Willem van Eetveldt

Affiliation

Johannesburg Bar,

South Africa

Email

Mariushve@counsel.co.za

Date Submission

15 October 2017

Date Revised

4 February 2019

Date Accepted

4 February 2019

Date published

18 March 2019

Editor Prof H Chitimira

How to cite this article

Van Eetveldt $\mathrm{H}$ "Standing on Unsteady Ground: AREVA NP Incorporated in France $v$ Eskom SOC LTD" PER / PELJ 2019(22) DOI

http://dx.doi.org/10.17159/17273781/2019/v22i0a3285

\section{Copyright}

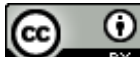

DOI

http://dx.doi.org/10.17159/17273781/2019/v22i0a3285

\begin{abstract}
Areva NP Incorporated in France $v$ Eskom Holdings SOC Ltd 20176 BCLR 675 (CC) was a dispute over a multi-billion-rand tender. Although the majority of the Constitutional Court recognised the public importance of the case, it adjudicated the dispute entirely on a preliminary point. It found that the applicant did not have legal standing to seek the judicial review of the award of the tender.

This case note has three aims. First, I will argue that the Constitutional Court's majority judgment in Areva was generally unpersuasive. Second, I will attempt to show that Areva exposes an unresolved legal question: when should a court consider the merits of a case made by a litigant with questionable standing? Third, I will propose a method for resolving this question by way of substantive judicial reasoning in any given case.
\end{abstract}

\section{Keywords}

Locus standi; legal standing; public-procurement; tender-dispute; substantive reasoning; transformative adjudication. 


\section{Introduction}

Areva NP Incorporated in France v Eskom Holdings SOC Ltd' was a dispute over a multi-billion-rand ${ }^{2}$ tender. Although the majority of the Constitutional Court recognised the public importance of the case ${ }^{3}$ it adjudicated the dispute entirely on a preliminary point. It found that the applicant in the court of first instance, Westinghouse Electric Belgium Société Anonyme (hereafter referred to as Westinghouse), did not have legal standing to seek the judicial review of the award of the tender. ${ }^{4}$

This case note has three aims. First, I will argue that the Constitutional Court's majority judgment in Areva was generally unpersuasive. Second, I will attempt to show that Areva exposes an unresolved legal question: when should a court consider the merits of a case made by a litigant with questionable standing? Third, I will propose a method for resolving this question in any given case. I start by briefly considering the development of the law on legal standing, as this provides the context for the ensuing discussion.

\section{A broadened approach to legal standing}

Legal standing determines whether a particular litigant is entitled to approach a court for relief. ${ }^{5}$ It is a tool a court uses to determine if a litigant "is entitled to claim its time, and to put the opposing litigant to trouble." 6 To obtain legal standing, a litigant must meet two overarching requirements: he must have the capacity to litigate, and a sufficient interest in the matter before the court. ${ }^{7}$ The sufficient-interest requirement is generally of greater concern to litigation with a public-law dimension. ${ }^{8}$ This is exemplified by the facts in Areva: no one challenged Westinghouse's capacity to litigate; however, it was contentious whether it satisfied the sufficient-interest

\footnotetext{
* Henri-Willem van Eetveldt. BA BA(Hons) LLB LLM (Stellenbosch University). Advocate, member of the Johannesburg Bar. E-mail: hve@counsel.co.za. Areva NP Incorporated in France v Eskom Holdings SOC Ltd 20176 BCLR 675 (CC) (hereafter referred to as Areva).

Areva para 4.

Areva para 27.

Areva para 42.

Giant Concerts CC v Rinaldo Investments (Pty) Ltd 20133 BCLR 251 (CC) para 34 (hereafter referred to as Giant Concerts). Giant Concerts para 41. Hoexter Administrative Law 487. Baxter Administrative Law 644; Hoexter Administrative Law 487.
} 
requirement. As such, I consider only the sufficient-interest requirement in this note.

Under common law before 1994, a litigant would have legal standing only if he had a sufficient, direct, and personal interest in the matter before the court. ${ }^{9} \mathrm{~A}$ court would recognise that the litigant possessed such an interest only if the litigant was personally adversely affected by the impugned act. ${ }^{10}$ It would not suffice to show that the impugned act harmed the public in general: there had to be a personal nexus between the litigant and the impugned act. ${ }^{11}$

Our common law thus allowed only a narrow range of persons to be heard by the courts. Moreover, particularly in administrative-law disputes, courts were prone to apply the rules on standing formalistically. ${ }^{12}$ The common law on standing was therefore doubly restrictive: its rules were stringent and its judicial approach was narrow. ${ }^{13}$

Section 38 of the Constitution of the Republic of South Africa, 1996 (hereafter the Constitution) and its predecessor, section 7(4) of the Constitution of the Republic of South Africa 200 of 1993 (hereafter the Interim Constitution) introduced a "radical departure"14 from the common law on standing. Section 38 of the Constitution states:

Anyone listed in this section has the right to approach a competent court, alleging that a right in the Bill of Rights has been infringed or threatened, and the court may grant appropriate relief, including a declaration of rights. The persons who may approach a court are -

(a) anyone acting in their own interest;

(b) anyone acting on behalf of another person who cannot act in their own name;

Hoexter Administrative Law 488-489; Currie and De Waal Bill of Rights Handbook 73; Budlender and Webber "Standing and Procedure for Judicial Review" 222.

10 Currie and De Waal Bill of Rights Handbook 73.

11 Baxter Administrative Law 654. Although Roman law recognised a range of "popular actions" which clothed a litigant with standing to vindicate the public interest, these actions expired in Roman-Dutch law. See Dalrymple $v$ Colonial Treasurer 1910 TS 372 380; Wood v Ondangwana Tribal Authority 19752 SA 294 (A) 308B-C. The only exception was the interdictum de libero homine exhibendo. This remedy, the equivalent of the English writ of habeas corpus, was directed at freeing a person from unlawful detention. See Wood v Ondangwana Tribal Authority 19752 SA 294 (A) 308F-310G. See also, Swanepoel 2014 De Jure 65-66.

12 Hoexter 2008 SAJHR 288.

$13 \quad$ For a notable exception, see Jacobs $v$ Waks 19921 SA 521 (A) 534B-E.

14 Lawyers for Human Rights v Minister of Home Affairs 20044 SA 125 (CC) para 14. 
(c) anyone acting as a member of, or in the interest of, a group or class of persons;

(d) anyone acting in the public interest; and

(e) an association acting in the interest of its members.

It is plain from the text of section 38 that the Constitution affords standing to litigants that are not personally adversely affected by the law or conduct they impugn. Section 38(c), for instance, allows a litigant to act in the interest of a class of persons, while section 38(d) allows a litigant to act in the interest of the public at large. This is clearly a departure from the commonlaw position.

The Constitution not only expanded the rules on standing, but it also expanded the approach courts should use to interpret and apply those rules. In Ferreira $v$ Levin; Vryenhoek $v$ Powell, ${ }^{15}$ the Constitutional Court (per Chaskalson P) held:

\begin{abstract}
Whilst it is important that this Court should not be required to deal with abstract or hypothetical issues, and should devote its scarce resources to issues that are properly before it, I can see no good reason for adopting a narrow approach to the issue of standing in Constitutional cases. On the contrary, it is my view that we should rather adopt a broad approach to standing. This would be consistent with the mandate given to this Court to uphold the Constitution and would serve to ensure that Constitutional rights enjoy the full measure of the protection to which they are entitled. ${ }^{16}$
\end{abstract}

In a separate concurring judgment, O'Regan $\mathrm{J}$ explained the rationale for this broadened judicial approach. O'Regan $\mathrm{J}$ pointed out that the commonlaw rules on standing developed in the context of private litigation, which involves disputes between private individuals. Generally, such litigation does not affect people that are not parties to the dispute before the court. ${ }^{17}$ In litigation with a public dimension, however, the relief sought may affect a wide range of people who are not parties to the dispute, and the alleged harm may "be quite diffuse or amorphous". ${ }^{18}$ Although O'Regan $\mathrm{J}$ was careful not to construct an artificial binary distinction between private and public litigation, ${ }^{19}$ she pointed out that section $7(4)$ of the Interim Constitution

\footnotetext{
15 Ferreira $v$ Levin; Vryenhoek $v$ Powell 19961 SA 984 (CC) (hereafter referred to as Ferreira $v$ Levin).

$16 \quad$ Ferreira $v$ Levin para 165.

$17 \quad$ Ferreira $v$ Levin para 229.

$18 \quad$ Ferreira $v$ Levin para 229.

19 Ferreira $v$ Levin para 229G-H.
} 
broadened the law on standing specifically to accommodate public litigation's unique features. ${ }^{20}$

Section 38(a) of the Constitution regulates the standing of a litigant acting in its own interest. This ground of standing was particularly relevant in Areva, as Westinghouse averred that it was acting in its own interest. Section 38(a) appears to reiterate the common-law standard for establishing own-interest standing. ${ }^{21}$ But, as confirmed by Cameron J in Giant Concerts, the standard for own-interest standing under section 38(a) is much broader than the common-law standard. ${ }^{22}$ Cameron $\mathrm{J}$ explained, with reference to Ferreira $v$ Levin, ${ }^{23}$ that although an own-interest litigant must show that the impugned act directly affects his or her interests or potential interests, it is unnecessary to demonstrate the personal nexus that the common law required. 24

Cameron $\mathrm{J}$ reiterated that the own-interest-standing requirement must be broadly interpreted. ${ }^{25} \mathrm{He}$ held that court should keep in mind that standing is "not a technical or strictly-defined concept", that there is "no magical formula for conferring it", and that it should be determined pragmatically with reference to the facts of the case before the court. ${ }^{26}$

Cameron $\mathrm{J}$ also held that a court should consider questions of standing before it engages with the merits of the case. ${ }^{27}$ This has important consequences. ${ }^{28}$ It means that standing is not determined by the merits of a legal challenge, but rather with the relationship between the challenge and the interests of the party seeking to make it. As such, an own-interest litigant may be denied standing even if this means that irregular conduct is obscured from judicial scrutiny. ${ }^{29}$

But the separation between standing and merits is not absolute. Cameron $\mathrm{J}$ indicated that there may be cases where a court will consider the merits

\footnotetext{
$20 \quad$ Ferreira $v$ Levin para $229 \mathrm{H}$.

21 Hoexter Administrative Law 492.

$22 \quad$ Giant Concerts para 41.

23 Cameron $\mathrm{J}$ also referred to Minister of Home Affairs $v$ Eisenberg \& Associates: In re Eisenberg \& Associates Minister of Home Affairs 20035 SA 281 (CC); Kruger v President of Republic of South Africa 20091 SA 417 (CC).

$24 \quad$ Giant Concerts para 41.

$25 \quad$ Giant Concerts para 41.

$26 \quad$ Giant Concerts para 41.

$27 \quad$ Giant Concerts para 32.

28 Giant Concerts paras 33-34.

$29 \quad$ Giant Concerts para 34.
} 
of a challenge brought by a litigant with questionable standing. ${ }^{30}$ According to Cameron J:

[T]he interests of justice under the Constitution may require courts to be hesitant to dispose of cases on standing alone where broader concerns of accountability and responsibility may require investigation and determination of the merits. ${ }^{31}$

For reasons I will explain below, I am of the view that this proposition is particularly relevant to Areva, and raises questions that the law on standing does not currently answer. I refer to the proposition as the "Giant-Concerts exception" for ease of reference. ${ }^{32}$ I will now consider Areva, starting with the background to the dispute.

\section{Background to the dispute in Areva}

Areva was a dispute about a tender for the replacement of steam generators in the Koeberg nuclear power station. ${ }^{33}$ The periodic replacement of these generators is vital to the sustainability of South-Africa's electricity resources. ${ }^{34}$ Eskom SOC Ltd (hereafter referred to as Eskom), the organ of state responsible for the power station, was of the view that it was a nuclear safety priority that the generators had to be replaced by $2018 .{ }^{35}$

In 2012 Eskom called for expressions of interests to replace the generators. ${ }^{36}$ Two companies responded to Eskom's satisfaction: Westinghouse and Areva NP Incorporated in France (hereafter referred to as Areva). ${ }^{37}$ Eskom allowed both companies to submit bids. ${ }^{38}$ It evaluated the bids rigorously. ${ }^{39}$ It ultimately decided to award the tender to Areva. ${ }^{40}$

Westinghouse initiated litigation in the High Court shortly thereafter. ${ }^{41}$ It sought the judicial review of Eskom's decision to award the tender to Areva. It also sought a substitution order, i.e. that the tender be awarded to it. ${ }^{42}$

$30 \quad$ Giant Concerts para 34

$31 \quad$ Giant Concerts para 34.

32

It is an "exception" in the sense that it is a departure from the rule that a court will only consider the merits of a legal challenge made by a litigant with standing.

33 Areva para 4.

$34 \quad$ Westinghouse Electric Belgium SA v Eskom Holdings SOC Ltd 20163 SA 1 (SCA) para 6 (hereafter Areva SCA).

$35 \quad$ Areva SCA para 6.

$36 \quad$ Areva para 5.

$37 \quad$ Areva para 6.

$38 \quad$ Areva para 7.

39 Areva SCA paras 8-30.

$40 \quad$ Areva para 12.

$41 \quad$ Areva para 13.

$42 \quad$ Areva para 13. 
Westinghouse essentially averred that Eskom awarded the tender to Areva on the strength of criteria outside the bid-evaluation criteria set out in the tender documents. ${ }^{43}$ According to Westinghouse, this was an irregularity that made Eskom's decision reviewable on several grounds under the Promotion of Administrative Justice Act 3 of 2000 (hereafter referred to as the PAJA). ${ }^{44}$

Both Eskom and Areva opposed Westinghouse's application on the merits. Unlike Eskom, Areva also disputed Westinghouse's legal standing. Areva argued that Westinghouse had not submitted its own bid but had submitted a bid as an agent of another company, Westinghouse Electric Company LLC (hereafter referred to as Westinghouse USA). As Westinghouse was not a bidder, Areva argued, Westinghouse did not have a sufficient interest to impugn Eskom's decision to award the tender to Areva. ${ }^{45}$

Both the High Court ${ }^{46}$ and the Supreme Court of Appeal ${ }^{47}$ found that Westinghouse had legal standing.

\section{Judgment of the Constitutional Court}

\subsection{The relationship between Westinghouse and Westinghouse USA}

Before the Constitutional Court Areva persisted with its challenge to Westinghouse's standing. Westinghouse maintained that it had standing to impugn Eskom's decision because it had submitted its own bid. ${ }^{48}$ As far as its relationship with Westinghouse USA was concerned, Westinghouse averred that it merely received the "support" of Westinghouse USA, ${ }^{49}$ as both Westinghouse USA and it belonged to the Westinghouse group of companies.

The majority of the Constitutional Court, in a judgment authored by Zondo $\mathrm{J}$, accepted Areva's argument. It found that Westinghouse was the agent of

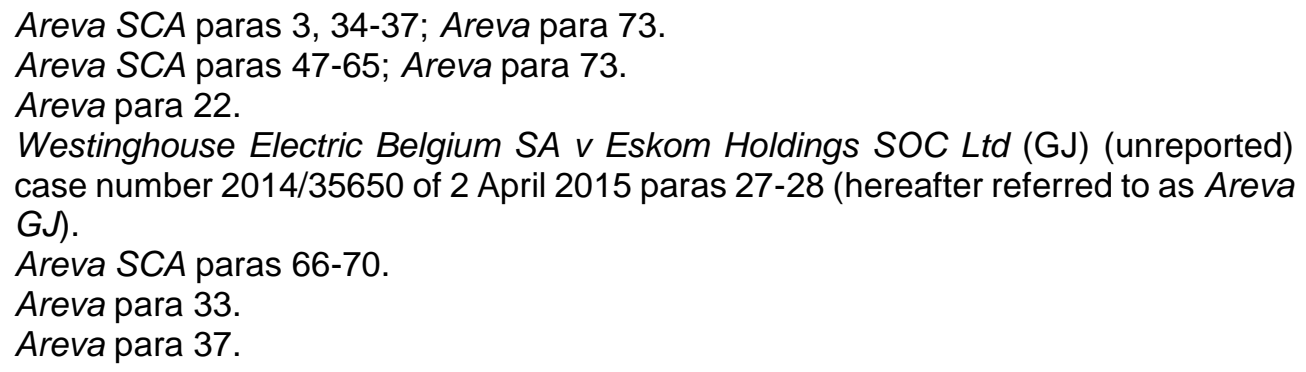


Westinghouse USA and that Westinghouse did thus not have a sufficient interest in Eskom's decision to award the tender to Areva. ${ }^{50}$

It seems that the majority found that Westinghouse was the agent of Westinghouse USA after narrowly parsing minute detail in the documentary evidence. It seems to have relied almost exclusively on the following phrase, which appeared in one sentence of a letter sent by Westinghouse to Eskom:

Westinghouse Electric Belgium on behalf of Westinghouse Electric Company LLC is pleased to submit the present offer to Eskom. ${ }^{51}$

The majority was admirably conscientious in its attention to detail. But it may have been so narrowly focussed on evidentiary minutiae that it failed to adopt a broad approach to the facts. The majority held, for instance, that if the abovementioned letter did not show that Westinghouse was an agent of Westinghouse USA, "then nothing will". ${ }^{52}$ Perhaps that is so. But this does not exclude the possibility that there could be equally compelling countervailing evidence. Yet the majority treated the letter as if it excluded the possibility of such evidence.

There were also factual indications that Westinghouse was a bidder in its own right. These were considered by the minority, which took a broader, pragmatic approach to the facts. Beside the fact that Westinghouse said on affidavit that it was a bidder, the minority also took into account that during the bid-evaluation process Westinghouse and Westinghouse USA acted in concert. It also took into account the fact that Eskom never doubted that Westinghouse would replace the steam generators. ${ }^{53}$ While the majority saw the abovementioned letter as proof that Westinghouse was the agent of Westinghouse USA, the minority saw the letter as showing only that "a party may have mixed up its corporate identity within the litigating multinational group of companies". 54

Now, if Westinghouse submitted a bid as an agent of Westinghouse USA, the majority was correct to reject Westinghouse's argument that its interests as a bidder were affected by Eskom's decision: if Westinghouse submitted a bid as an agent, it could not have submitted the same bid in its own right. ${ }^{55}$

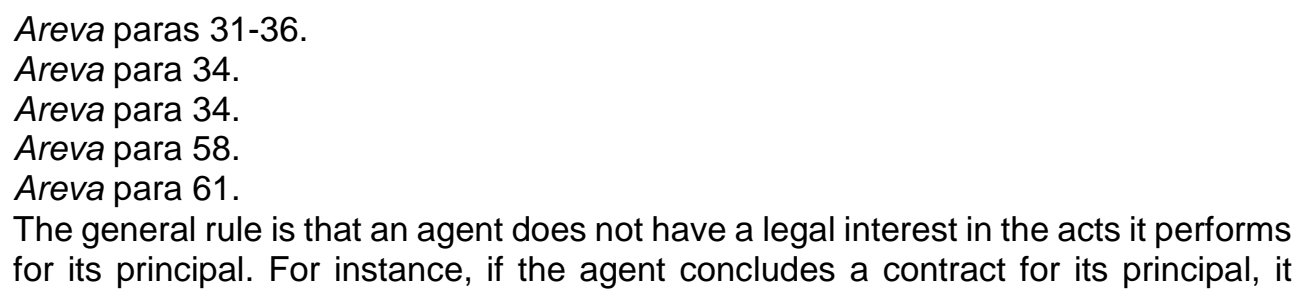


But the majority could perhaps have done more to explain the ambit of its factual finding. It seemed to imply that Westinghouse failed because - as a rule - only bidders have own-interest standing to challenge tender awards. It held, for example, that as Westinghouse was not a bidder, Eskom's decision to award the tender to Areva could not possibly have adversely affected Westinghouse's interests or potential interests. ${ }^{56}$ But it is arguably not a rule that only a bidder will have own-interest standing to challenge the award of a tender. For example, a litigant may challenge a tender precisely because an organ of state failed to provide the litigant with a fair opportunity to submit a bid for the tender. ${ }^{57}$

It would have been useful if the majority made this clear. This would have reduced the possibility of confusion in future cases. It would also have emphasised that, as far as legal standing in a public-procurement case is concerned, the key question is whether a litigant has a sufficient interest in the impugned act, and not whether the litigant was a bidder or not. Focussing on whether a litigant was a bidder or not facilitates a narrow approach to standing. This is not the approach that the Constitution demands. ${ }^{58}$

The majority was dismissive of the fact that Westinghouse and Westinghouse USA belonged to the same group of companies. It pointed out that even if the two companies belonged to the same company-group, they remained separate legal entities with their own rights and obligations. ${ }^{59}$ Thus, if Westinghouse USA acquired rights and obligations because it submitted a bid, those rights and obligations would not be shared by Westinghouse simply because Westinghouse also belonged to the

cannot personally sue or be sued under the contract. The agent can also not sue or be sued as the representative of the principal, unless the principal authorises the agent to represent it in that capacity. On the general rule, see Waikiwi Shipping Co Ltd $v$ Thomas Barlow and Sons (Natal) Ltd 19781 SA 671 (A) 680D. However, the general rule is subject to several exceptions. A pertinent exception is that an agent may sue personally where he has a special interest in the subject matter of a contract he concludes for the principal. See Continental Illinois National Bank and Trust Co of Chicago v Greek Seamen's Pension Fund 19892 SA 515 (D) 538H-542C. It falls beyond this note's reach to discuss the law of agency in any detail. Areva para 36.

See, for example, Secureco (Pty) Ltd v Ethekwini Municipality (KZD) (unreported) case number 1100/2015 of 1 April 2016.

Ferreira v Levin para 165.

Areva paras 37-38. 
Westinghouse group of companies. ${ }^{60}$ In this regard, the majority stressed that "[t]he issue here is about legal entities"..61

Hence the majority applied the principle of separate juristic personality. The principle is, of course, a cornerstone of our company law. ${ }^{62}$ But the principle has less significance in the context of legal standing than the majority appears to have believed. In my view, in emphasising that "[t]he issue here is about legal entities", the majority oversimplified the legal position. As I see it, the issue at root was not that Westinghouse and Westinghouse USA were different companies. The issue at root was that Westinghouse failed to explain how its interests aligned with Westinghouse USA in respect of the tender. The fact that Westinghouse was not the same company as Westinghouse USA did not, in principle, preclude such an explanation. It would all depend on the relationship between the companies, and whether this relationship gave Westinghouse a sufficient interest in Eskom's decision to award the tender to Areva. In insisting that "[t]he issue here is about legal entities", the majority seems, curiously, to have evoked the common-law requirement of a personal nexus between the litigant and the act it seeks to challenge.

The majority thus found that Westinghouse lacked legal standing to impugn Eskom's decision to award the tender to Areva. This may have been the correct outcome. The majority appears, however, to have oversimplified the law on legal standing in reaching the outcome. This could lead to confusion in future cases dealing with a litigant's own-interest standing to challenge the award of a public tender.

\subsection{The Giant Concerts exception}

The majority proceeded to find that the Giant Concerts exception did not apply to the facts in Areva. ${ }^{63}$ It found, in other words, that because Westinghouse lacked standing it would not be justifiable to assess the merits of its claim. The majority's reasoning for this finding occurs in one paragraph, which I quote in full for ease of reference:

It seems to me that, part of what this Court held in Giant Concerts was that, where a litigant has failed to show that it has standing, the Court should, as a general rule, dispose of the matter without entering the merits and that it should only enter the merits in exceptional cases or where the public interest really cries out for that. It does not appear to me that this is a case which cries

Areva paras 37-38.

Areva para 39.

See generally, Cassim Contemporary Company Law 31-65.

Areva paras 40-41. 
out for that. In saying this, I am not suggesting that on the merits the challenge is necessarily without merit but I do so because: (a) the two bidders appear to have been neck and neck in the competition for the tender; (b) both bidders were accepted as technically capable of doing the job properly; and (c) time is of the essence in regard to the installation and replacement of the steam generators and, if the steam generators are not installed and replaced on time, there may be severe consequences for the country in regard to nuclear energy. Furthermore, Areva has been working on the project for the past two years and there is not much left before the time by when the installation and replacement of the generators is required to have been completed.

I read this paragraph as containing three distinct reasons for the conclusion that the Giant Concerts exception did not apply to the facts in Areva. I will discuss each reason in turn. In my respectful view, none of the reasons are persuasive.

\subsubsection{Areva and Westinghouse were evenly-matched bidders}

The majority held that the Giant Concerts exception was not applicable because Areva and Westinghouse were "neck and neck in the competition for the tender", ${ }^{64}$ and both companies were technically competent to replace the steam generators. In making these statements, the majority could have been saying at least two different things.

The majority could have meant that the case did not "cry out" for relief because Areva and Westinghouse were evenly-matched bidders. In terms of this line of reasoning, the case would presumably have "cried out" for relief if Areva had been an inferior bidder or if it had been incapable of replacing the steam generators.

If this is indeed what the majority meant, it overlooked an important principle of law: in determining a litigant's standing, a court must assume that the litigant's complaints about the impugned act are correct. ${ }^{65}$ According to Westinghouse, its bid was some R140 000000 cheaper than Areva's bid. ${ }^{66}$ Although R140 000000 is far less than the value of the contract between Eskom and Areva, which is approximately R5 000000000,67 it is still a significant amount of money. If Westinghouse's bid was more cost-effective by R140 000 000, the dispute in Areva did, in my view, "cry out" for relief.

But perhaps all of this misses what the majority actually meant. The majority could also have meant this: Areva and Westinghouse were equally

\footnotetext{
$64 \quad$ Areva para 41.

65 Jacobs v Waks 19921 SA 521 (A) 536A; Giant Concerts para 32.

66 Areva SCA para 4.

67 Areva GJ para 2.
} 
deserving of the tender. So if the impugned decision were remitted to Eskom - and if Eskom again decided to award the tender - it would not necessarily award the tender to Westinghouse. Hence Westinghouse could not get the substitution order it sought ${ }^{68}$ and its challenge was therefore academic. ${ }^{69}$

If this is indeed what the majority meant, its reasoning was unsound for two reasons. First, Westinghouse did not only seek a substitution order - it also asked the court to set aside Eskom's decision to award the tender to Areva. ${ }^{70}$ Even if Westinghouse could not get the substitution order it sought, a court could still order that Eskom's decision be set aside. This is what the Supreme Court of Appeal did, for instance. ${ }^{71}$ Accordingly, even if Westinghouse's prayer for a substitution order was academic, this did not mean its entire application was academic.

Second, if the majority considered whether Westinghouse was entitled to a substitution order, this is something it should have considered during the remedy stage of its enquiry. The enquiry into standing precedes the enquiry into the merits, and each enquiry turns on different considerations. ${ }^{72}$ Equally, the enquiry into merits precedes the enquiry into the appropriate remedy, and both enquiries again attract different considerations. ${ }^{73}$ The enquiry into a remedy is therefore twice removed from the enquiry into standing. As such, the majority should not have conflated the question whether Westinghouse had an interest in the tender with the question whether the tender should be awarded to Westinghouse.

68 In Trencon Construction (Pty) Ltd $v$ Industrial Development Corporation of Southern Africa Ltd 20155 SA 245 (CC) paras 34-59, the Constitutional Court confirmed that a substitution order under $s 8(1)(c)(i i)(a a)$ of the PAJA is an extraordinary remedy. The Constitutional Court held that the remedy should be granted only where two related factors are both present. First, the court should be in as good a position as the administrator to make the impugned decision. Second, if the administrator had to make the impugned decision again, it would have to be a foregone conclusion that the administrator would make the decision in favour of the party seeking the substitution order. A court may thereafter consider other relevant factors and must ultimately decide whether it would be just and equitable to grant the substitution order. An interest is "academic" where it is not related to a real or practical situation. See Giant Concerts para 51.

Areva para 2.

Areva SCA para 80.

Hoexter Administrative Law 488; Giant Concerts para 33.

Bengwenyama Minerals (Pty) Ltd v Genorah Resources (Pty) Ltd 20114 SA 113 (CC) para 84; AllPay Consolidated Investment Holdings (Pty) Ltd v Chief Executive Officer, South African Social Security Agency 20141 SA 604 (CC) paras 24-26, 56 (hereafter referred to as AlIPay 1). 


\subsubsection{Time was of the essence}

The majority held that the Giant Concerts exception was not applicable because the steam generators had to be replaced timeously, as a delay would endanger the public. ${ }^{74}$ This is obviously a compelling reason. But the problem, as pointed out by the minority, ${ }^{75}$ is that it is an equally good reason for considering Westinghouse's case on the merits.

If Westinghouse failed on standing alone - and if it failed on standing simply because it cited the wrong party as the applicant - it might have been motivated to make a new application in the name of Westinghouse USA. A fresh application could have protracted the dispute even further. It would thus have been prudent to ensure that fresh litigation did not occur. One way of doing this would have been to adjudicate Westinghouse's case once and for all.

\subsubsection{Areva had already started performing the tender}

Finally, the majority held that the Giant Concerts exception did not apply because Areva had already started performing the tender. ${ }^{76}$ The majority did not explain its reasoning here. It simply stated that Areva had "been working on the project for the past two years" and the deadline for the completion of its work was imminent. ${ }^{77}$ I assume the majority meant that Westinghouse's application was academic, because even if the majority found the decision to be invalid, it would use its discretion to preserve the contract between Eskom and Areva. ${ }^{78}$

If that is indeed what the majority meant, it again conflated the remedyenquiry with the standing-enquiry. Whether Eskom's decision should be set aside is a question to be considered in the remedy-enquiry. It is twice removed from the question that animates the standing-enquiry, namely whether Westinghouse was an appropriate litigant to challenge Eskom's decision.

Areva para 41.

Areva para 62.

Areva para 41.

Areva para 41.

For examples of public-procurement cases where courts have been willing to use their discretion in this way, see Chairperson, Standing Tender Committee $v$ JFE Sapela Electronics (Pty) Ltd 20082 SA 638 (SCA); Moseme Road Construction CC $v$ King Civil Engineering Contractors (Pty) Ltd 20104 SA 539 (SCA). But compare Eskom Holdings Ltd v New Reclamation Group (Pty) Ltd 20094 SA 628 (SCA). 


\section{When should a court consider the merits of a case made by a litigant with questionable standing?}

\subsection{Introduction}

So far I have focussed on the Constitutional Court's majority judgment in Areva. I have argued that the judgment oversimplified the law regulating the legal standing of the own-interest litigant. I have further argued that the majority's reasoning was unpersuasive in deciding that the Giant Concerts exception did not apply to the case at hand.

My focus now shifts to the Giant Concerts exception itself. I will attempt to show that the meaning of the Giant Concerts exception is unsettled. I will argue, in other words, that it is unclear when a court should consider the merits of a case made by a litigant with questionable standing. I will finally propose a method for dealing with this unresolved legal question.

\subsection{Three interpretations}

In Areva, the majority of the Constitutional Court held that the Giant Concerts exception applies only where "the public interest really cries out for that". ${ }^{79}$ For ease of reference, I will call this "the crying-out interpretation".

According to the crying-out interpretation, a court will consider a case made by a litigant with questionable standing only if the case is obviously exceptional. It is doubtful whether such a restrictive interpretation is congruent with the broad approach to standing that the Constitution demands. However, there is some indication that the Giant Concerts exception was indeed designed to be restrictive. This can be found in the penultimate paragraph of Giant Concerts, where Cameron J wrote:

\footnotetext{
When a party has no standing, it is not necessary to consider the merits, unless there is at least a strong indication of fraud or other gross irregularity in the conduct of a public body. ${ }^{80}$
}

In Tulip Diamonds FZE v Minister of Justice and Constitutional Development ("Tulip Diamonds"), ${ }^{81}$ the Constitutional Court read this proposition and the Giant Concerts exception together. The Court in Tulip Diamonds held, in other words, that the Giant Concerts exception applied only where there is a strong indication of fraud or other gross irregularity by the organ of state

Areva para 41.

Giant Concerts para 58.

Tulip Diamonds FZE v Minister of Justice and Constitutional Development 20132

SACR 443 (CC) (hereafter referred to as Tulip Diamonds). 
concerned. ${ }^{82}$ This is a further indication that the Giant Concerts exception should be read restrictively. For ease of reference, I will call this "the Tulip Diamonds interpretation".

It is doubtful whether the Tulip Diamonds interpretation is cogent. It blends two propositions from Giant Concerts. The first proposition, which appears at paragraph 34 of Giant Concerts, is about a litigant with questionable standing. ${ }^{83}$ The second proposition, which appears 24 paragraphs later, is about a litigant with no standing. ${ }^{84}$ These propositions are formally and substantively different. It is therefore questionable whether the Constitutional Court in Tulip Diamonds should have read the propositions together.

It is also noteworthy that in Areva the Constitutional Court did not refer to the Tulip Diamonds interpretation at all. This is a strange oversight. But perhaps it means that that the Tulip Diamonds interpretation has little precedential influence.

In contrast to the Tulip Diamonds interpretation and the crying-out interpretation, the minority in Areva interpreted the Giant Concerts proposition as laying down a flexible standard. According to the minority, the import of the Giant Concerts exception is that a court will consider the merits of a case made by a litigant with questionable standing where it is in the interests of justice to do so. ${ }^{85}$ For ease of reference, I will call this "the open-ended interpretation".

Under the open-ended interpretation, a court has a wide discretion to decide whether it should consider the merits of a case made by a litigant with questionable standing. In exercising this discretion, the minority considered several factors that the majority failed to take into account. I briefly mention the two factors that are, to my mind, the most significant.

\subsubsection{Private litigation versus public litigation}

Unlike the majority, the minority took into account that Areva was not simply a commercial dispute between private entities, but that it was a publicprocurement dispute. ${ }^{86} \mathrm{~A}$ dispute of this nature attracts broader concerns of accountability: a contract flowing from a public-procurement process is

Tulip Diamonds para 45.

Giant Concerts para 34.

Giant Concerts para 58.

Areva paras 57, 60-62.

Areva para 61. 
concluded "not on the state entity's behalf, but on the public's behalf". ${ }^{87}$ The public has an interest in public procurement because it "palpably implicates socio-economic rights". ${ }^{88}$

In this regard, the minority could perhaps have emphasised that Areva concerned a particularly sensitive public-procurement dispute. As mentioned above, it concerned a five-billion-rand service that was crucial to the sustainability of the country's power grid and had to be performed as a nuclear safety priority.

The minority could also have engaged with the distinction between private litigation and public litigation, as discussed by O'Regan $\mathrm{J}$ in Ferreira $v$ Levin. ${ }^{89}$ The dispute in Areva may have seemed like private litigation: Westinghouse, a private company incorporated in Belgium, wanted a lucrative tender that Eskom awarded to Areva, a private company incorporated in France. But in substance it was public litigation. If Eskom awarded the tender to Areva irregularly, the resultant harm may have been "quite diffuse or amorphous"90 and may have affected not only Westinghouse but the public at large. The fact that Areva concerned public litigation underscores why a broad approach should have been used to assess Westinghouse's legal standing.

\subsubsection{The function of the Constitutional Court}

Unlike the majority, the minority also considered the role of the Constitutional Court as a factor guiding the application of the Giant Concerts exception. Commenting on the majority judgment, Moseneke DCJ wrote:

\footnotetext{
In my view, the judgment would have been stronger if, after disposing of the standing point, it went further to say: 'In any event, the appeal on the merits is without substance.' This approach speaks to an apex court that will not lightly look away at a potential injustice only because a party may have mixed up its corporate identity within the litigating multinational group of companies. ${ }^{91}$
}

This is an intriguing statement, as it evokes the debate about the function of the Constitutional Court. ${ }^{92}$ I cannot participate in the debate here, except to note that one's views on the function of the Constitutional Court will likely correlate with one's views on the meaning of the Giant Concerts exception.

AllPay 1 para 56.

AllPay 1 para 4.

See section 2 above.

Ferreira $v$ Levin para 229.

Areva para 61.

See, for instance, Currie 1999 SAJHR 138-165; Roederer 1999 SAJHR 486-512;

Fowkes 2013 CCR 309-330; Cachalia 2017 SAJHR 138-153. 
If one believes that the Constitutional Court functions primarily to adjudicate the dispute between the parties before it, one would likely give a cautious reading of the Giant Concerts exception. However, if one believes that the Constitutional Court is also responsible to provide guidance on constitutional issues - even if litigants present those issues to the Court abnormally or in a procedurally deficient way - one would likely give a generous reading of the Giant Concerts exception.

\subsection{Formal and substantive reasoning}

What underlies these different interpretations of the Giant Concerts exception? The most plausible explanation, in my view, is that the interpretations are produced by different approaches to adjudication itself.

This difference in approach can be articulated in terms of a distinction that has gained currency in South-African legal theory: the distinction between formal and substantive reasoning. ${ }^{93}$ This distinction originates from Atiyah and Summers' well-known comparative study of the American and English legal systems. ${ }^{94}$ On the basis of the distinction, Atiyah and Summers build a theory of adjudication the details of which I will not discuss here, as that would require an entire article on its own. For the purpose of this note I thus merely outline their general proposition in broad terms.

According to Atiyah and Summers, a substantive reason is a "moral, economic, political, institutional, or other social consideration." ${ }^{95} \mathrm{~A}$ formal reason is a "legally authoritative reason on which judges and others are empowered or required to base a decision or action." ${ }^{96}$ Formal reasons seek to oust countervailing substantive reasons. ${ }^{97}$ For example, a substantive reason for the delay rule in administrative law is that it promotes legal certainty ${ }^{98} \mathrm{~A}$ formal reason for the delay rule is that the PAJA commands that judicial-review proceedings must be instituted without unreasonable

93 Alfred Cockrell (Cockrell 1996 SAJHR 1-38) was one of the first to use this distinction to analyse the Constitutional Court's jurisprudence. The distinction is popular in the growing literature on the idea of transformative adjudication. For some of the most well-known contributions on this topic see, for instance, Moseneke 2002 SAJHR 309-319; Hoexter 2004 SALJ 598-599; Froneman 2005 Stell LR 3-20; Hoexter 2008 SAJHR 281-299; Quinot 2010 CCR 111-139; Hoexter 2015 SALJ 207-229. It falls beyond the scope of this note to itemise or discuss every contribution on the topic.

94 Atiyah and Summers Form and Substance 1-41.

95 Atiyah and Summers Form and Substance 1.

96 Atiyah and Summers Form and Substance 2.

$97 \quad$ Atiyah and Summers Form and Substance 2.

98 Wolgroeiers Afslaers (Edms) Bpk v Munisipaliteit van Kaapstad 19781 SA 13 (A) 41E-F; Oudekraal Estates (Pty) Ltd v City of Cape Town 20101 SA 333 (SCA) para 33. 
delay and within 180 days. ${ }^{99}$ From a purely formal point of view, then, if there has been a delay of 181 days there has been a legally prohibited delay, even if the delay has not created any legal uncertainty.

Drawing from Atiyah and Summers' analysis, several authors have argued that the post-apartheid Constitutional era demands a shift from a formal to a substantive "vision" of the law, in which substantive reasoning is favoured over formal reasoning. ${ }^{100}$ This "vision" does not require formal reasoning to be abandoned or established rules of law to be disregarded. Rather, it entails that, where courts apply formal rules, they should do so consistently with the substantive reasons underlying the rules. ${ }^{101}$

In the foregoing discussion I have attempted to illustrate that the majority judgment in Areva is characterised by a high degree of formal reasoning, while the minority judgment embraces substantive reasoning. In my view, the minority's substantive reasoning was more consistent with the broad approach to standing that the Constitution demands. The broad approach to standing is a matter of positive law, having been confirmed on numerous occasions since Ferreira $v$ Levin. ${ }^{102}$ There is no set of instructions for applying the approach, but it seems to flow from the very idea of a broad approach that it should be applied by way of substantive reasoning.

Substantive reasoning could also provide guidance on the import of the Giant Concerts exception. To date, courts have tried to ascertain the meaning of the exception by interpreting propositions from Giant Concerts. This exegesis is unlikely to yield a unanimous answer, as illustrated by the Tulip Diamonds interpretation, the crying-out interpretation, and the openended interpretation respectively. Of course, the Constitutional Court could simply state the meaning of the Giant Concerts exception by way of an unequivocal rule-like pronouncement, but this might undermine another proposition Cameron $\mathrm{J}$ asserted in Giant Concerts, namely that "there is no

\footnotetext{
99 Section $7(1)$ of the PAJA.

100 Cockrell 1996 SAJHR 7-9; Froneman 2005 Stell LR 3-5; Hoexter 2008 SAJHR 285286; Quinot 2010 CCR 111.

101 Quinot 2010 CCR 116.

102 See, for instance, De Reuck v Director of Public Prosecutions, Witwatersrand Local Division 20026 SA 370 (W) para 16; FirstRand Bank Ltd v Chaucer Publications (Pty) Ltd 20082 SA 592 (C) para 23; Freedom Under Law v Acting Chairperson: Judicial Service Commission 20113 SA 549 (CC) para 23; Savoi v National Director of Public Prosecutions 20145 SA 317 (CC) para 10; Giant Concerts para 41.
} 
magical formula" 103 for determining questions of standing, as each case turns on its own facts. ${ }^{104}$

It may be more productive for courts to perform the following two-step procedure in substantive reasoning to determine whether the Giant Concerts exception should apply in a particular case.

The first step is to determine what the substantive reasons are for limiting legal standing. In other words, a court should ask why we have rules on legal standing at all. The second step is to determine whether the underlying substantive reasons apply to the case at hand. In other words, a court should ask whether the underlying substantive reasons are good reasons for limiting a litigant's access to court in the case at hand. ${ }^{105}$

If the underlying reasons do not apply to the case at hand, this means that there are no substantive reasons for limiting the litigant's access to court. If there are no substantive reasons for limiting a litigant's right of access to court, it would be sensible to apply the Giant Concerts exception. Stated differently, it would be formalistic to maintain a strict barrier between the standing-enquiry and the merits-enquiry in circumstances whether the underlying reasons for a restriction on standing have dissolved. If there are minimal substantive reasons for maintaining the barrier but there are forceful countervailing reasons for removing it - such as indications of fraud, gross irregularity, and broader concerns of accountability and transparency - a court may also be inclined to apply the Giant Concerts exception.

To show what this two-step exercise looks like in practical terms, I will now perform it on the facts of Areva. I will focus on three well-known justifications for limiting legal standing.

\subsubsection{The floodgates-of-litigation justification}

A popular justification for limiting legal standing is the floodgates-of-litigation argument. ${ }^{106}$ The argument, simply put, is that courts will be overburdened by unmeritorious claims if legal standing is unlimited. The Constitutional

\footnotetext{
103 Giant Concerts para 42.

104 Giant Concerts para 42.

105 It seems that the Constitutional Court used a similar method in Ferreira $v$ Levin para 164.

106 Baxter Administrative Law 645; Hoexter Administrative Law 489-490.
} 
Court has expressed a similar idea by saying that it "should devote its scarce resources to issues that are properly before it". 107

The floodgates argument finds no traction in Areva. As noted above, Areva was a public-procurement dispute. As far as these disputes are concerned, the floodgates are apparently already open. In 2010 the Supreme Court of Appeal noted that courts "are swamped with unsuccessful tenderers that seek to have the award of contracts set aside and for the contracts to be awarded to them."108 As far as I am aware the flood of public-procurement litigation has not subsequently abated. So, if the Giant Concerts exception applied to the facts in Areva, this would not have opened the floodgates of litigation.

Furthermore, even if applying the Giant Concerts exception in Areva would somehow have opened the floodgates of litigation, it is debatable whether this would have been a bad thing. Because public-procurement disputes invariably attract broader concerns of accountability and transparency, it is perhaps desirable that such disputes are often subjected to judicial scrutiny. In the words of Pickering $\mathrm{J}$, "it may sometimes be necessary to open the floodgates in order to irrigate the arid ground below them."109

The resource-scarcity argument also does not work in the context of the dispute in Areva. This is because the Constitutional Court in fact devoted its scarce resources to the case. It considered the parties' affidavits and other court papers, ${ }^{110}$ it heard the parties' submissions, including their submissions on the merits, ${ }^{111}$ and it produced two judgments. If the majority applied the Giant Concerts exception, its only remaining work would have been to write the additional paragraphs dealing with the merits of Westinghouse's case. It is unlikely that this would have been an onerous additional burden on the Constitutional Court's resources.

\footnotetext{
$107 \quad$ Ferreira $v$ Levin para $41 \mathrm{n} 69$.

108 Moseme Road Construction CC v King Civil Engineering Contractors (Pty) Ltd 2010 4 SA 359 (SCA) para 1.

109 Wildlife Society of Southern Africa v Minister of Environmental Affairs and Tourism of the Republic of South Africa 19963 SA 1095 (TkS) 1106; Hoexter Administrative Law 491.

110 Areva paras 10-11, 17-21.

111 Areva para 61.
} 


\subsubsection{The best-litigant justification}

A further justification for limiting legal standing is the best-litigant argument. ${ }^{112}$ According to this argument, legal standing ensures that cases are presented to courts by litigants that are best equipped to do so, and this reduces the possibility that judges are faced with inchoate claims by vexatious litigants. ${ }^{113}$

From the judgment in Areva there is nothing to indicate that Westinghouse was not the best-placed litigant, or at least as well placed as Westinghouse USA. It seems that Westinghouse presented a comprehensive, rigorouslyargued case. Hence the best-litigant rationale is also not applicable to the facts in Areva.

\subsubsection{The justiciability justification}

A final justification for limiting legal standing is that it enables the judiciary to maintain its independence from the other branches of the state. ${ }^{114}$ The justification, in other words, is that courts can use legal standing to dispose of cases that are not justiciable. ${ }^{115}$ This justification clearly has no application to the facts in Areva, because it is trite that public-procurement disputes are justiciable. ${ }^{116}$

In summary, none of the main justifications for limiting legal standing apply to the facts in Areva. In my view, this is a good reason for concluding that, even if Westinghouse had questionable legal standing, it would have been justifiable to consider the merits of its application.

\subsubsection{Final remarks about the two-step procedure}

Two remarks about the two-step procedure are called for in closing.

The first remark is that the procedure is not intended to be a "jurisprudential slot-machine"117 that automatically generates the outcome of a case. The procedure does not intend to overlook the complexities in adjudication. Nor does it call for less analytic rigour in judicial decision-making. Instead it

\footnotetext{
112 Baxter Administrative Law 645; Hoexter Administrative Law 490; Budlender and Webber "Standing and Procedure for Judicial Review" 221.

113 Baxter Administrative Law 645; Hoexter Administrative Law 490.

114 Budlender and Webber "Standing and Procedure for Judicial Review" 221.

115 Hoexter Administrative Law 490.

116 See, for instance, Steenkamp v Provincial Tender Board, Eastern Cape 20073 SA 121 (CC) paras 21-22; AllPay 1 paras 4, 25.

117 Davis 2006 Acta Juridica 34.
} 
seeks to be a method for aligning adjudication in legal-standing cases with the broad approach demanded by the Constitution.

The second remark is about the rationale for the two-step procedure. The reader may ask: if I have argued for substantive over formal reasoning, what substantive reason do I propose for the two-step procedure itself?

The short answer to this question is that the two-step procedure works. That is to say, the two-step procedure provides a practical means of using substantive reasoning to decide whether the Giant Concerts exception should apply to the facts of a case. The procedure works because it is easy to understand, easy to replicate, and makes it virtually impossible to avoid substantive reasoning if used correctly.

The fact that the two-step procedure works might strike one as a flimsy justification: just because something works does not, of course, mean that it is good. Moreover, the fact that something "works" does not really sound like a "moral, economic, political, institutional, or other social consideration", which is Atiyah and Summers' definition of a substantive reason. ${ }^{118}$

But the fact that the two-step procedure works is significant in the light of the fact that the legal position is currently unworkable. There are currently three co-existing procedures for deciding whether the Giant Concerts exception should apply to the facts of a case, and it is not clear which procedure is, or should be, predominant. ${ }^{119}$ This multiplicity of competing procedures makes the legal position vague and unpredictable.

This basic and down-to-earth justification for the two-step procedure may come as a surprise and may even strike one as ironic. This is because pragmatic justifications, like certainty and expediency, are ordinarily justifications for formal and not substantive legal reasoning. ${ }^{120}$ But the point here is that such pragmatic justifications are still substantive justifications (they are called "second-level substantive reasons" by Atiyah and Summers), ${ }^{121}$ and they are justifications which are rooted in the Constitution. As the Constitutional Court has stated:

Whilst it may not be easy 'to avoid the influence of one's personal intellectual and moral preconceptions', this Court has from its very inception stressed the fact that 'the Constitution does not mean whatever we might wish it to mean'. Cases fall to be decided on a principled basis. Each case that is decided adds

\footnotetext{
118 Atiyah and Summers Form and Substance 1.

119 See the discussion under paragraph 5.2 above.

120 Atiyah and Summers Form and Substance 21.

121 Atiyah and Summers Form and Substance 21.
} 
to the body of South African constitutional law and establishes principles

relevant to the decision of cases which may arise in the future. ${ }^{122}$

\section{Conclusion}

I have made three arguments in this note.

The first argument is that the majority judgment in Areva was generally unpersuasive. The majority seems, at times, to have oversimplified the legal position. Moreover, in finding that the Giant Concerts exception did not apply to the facts in Areva, its reasoning was unconvincing.

The second argument is that the import of the Giant Concerts exception is not clear. In other words, it is unclear when exactly a court should consider the merits of a case made by an own-interest litigant with questionable standing. This is evidenced by co-existence of the Constitutional Court's crying-out interpretation, the Tulip Diamonds interpretation and the openended interpretation.

The final argument is that this gap in the law should be filled by the two-step procedure. This entails identifying the substantive reasons for limiting legal standing, and then deciding whether those reasons apply to the facts of the case at hand. The main benefit of this procedure is in my view that it is congruent with the broad approach to legal standing that the Constitution demands.

\section{Bibliography}

\section{Literature}

Atiyah and Summers Form and Substance

Atiyah PS and Summers RS Form and Substance in Anglo-American Law (Clarendon Press Oxford 1987)

Baxter Administrative Law

Baxter L Administrative Law (Juta Cape Town 1984)

\footnotetext{
122 Mistry v Interim Medical and Dental Council of South Africa 19984 SA 1127 (CC)
} para 3, citing S v Zuma 19952 SA 642 (CC) para 17. 
Budlender and Webber "Standing and Procedure for Judicial Review" Budlender S and Webber E "Standing and Procedure for Judicial Review" in Quinot G (ed) Administrative Justice in South Africa: An Introduction (Oxford University Press Cape Town 2016) 219-235

Cachalia 2017 SAJHR

Cachalia $\mathrm{R}$ "Botching Procedure, Avoiding Substance: A Critique of the Majority Judgment in My Vote Counts" 2017 SAJHR 138-153

Cassim Contemporary Company Law

Cassim FHI (ed) Contemporary Company Law $2^{\text {nd }}$ ed (Juta Cape Town 2012)

Cockrell 1996 SAJHR

Cockrell A "Rainbow Jurisprudence" 1996 SAJHR 1-38

Currie 1999 SAJHR

Currie I "Judicious Avoidance" 1999 SAJHR 138-165

Currie and De Waal Bill of Rights Handbook

Currie I and De Waal J The Bill of Rights Handbook $6^{\text {th }}$ ed (Juta Cape Town 2013)

Davis 2006 Acta Juridica

Davis D "To Defer and When? Administrative Law and Constitutional Democracy: The Constitutional Context" 2006 Acta Juridica 23-41

Fowkes 2013 CCR

Fowkes J "Managerial Adjudication, Constitutional Civil Procedure and Maphango v Aengus Lifestyle Properties" 2013 CCR 309-330

Froneman 2005 Stell LR

Froneman JC "Legal Reasoning and Legal Culture: Our 'Vision' of Law" 2005 Stell LR 3-20

Hoexter Administrative Law

Hoexter C Administrative Law in South Africa $2^{\text {nd }}$ ed (Juta Cape Town 2012)

Hoexter 2004 SALJ

Hoexter C "Contracts in Administrative Law: Life after Formalism?" 2004 SALJ 595-618 
Hoexter 2008 SAJHR

Hoexter C "Judicial Policy Revisited: Transformative Adjudication in Administrative Law" 2008 SAJHR 281-299

Hoexter 2015 SALJ

Hoexter C "The Enforcement of an Official Promise: Form, Substance, and the Constitutional Court" 2015 SALJ 207-229

Moseneke 2002 SAJHR

Moseneke D "The Fourth Bram Fischer Memorial Lecture: Transformative Adjudication" 2002 SAJHR 309-319

Quinot 2010 CCR

Quinot G "Substantive Reasoning in Administrative-Law Adjudication" 2010 CCR 111-139

Roederer 1999 SAJHR

Roederer C "Judicious Engagement: Theory, Attitude and Community" 1999 SAJHR 486-512

Swanepoel 2014 De Jure

Swanepoel CF "The Judicial Application of the 'Interest' Requirement for Standing in Constitutional Cases: 'A Radical and Deliberate Departure from the Common Law'" 2014 De Jure 63-84

\section{Case law}

AllPay Consolidated Investment Holdings (Pty) Ltd $v$ Chief Executive Officer, South African Social Security Agency 20141 SA 604 (CC)

Areva NP Incorporated in France v Eskom Holdings SOC Ltd 20176 BCLR 675 (CC)

Bengwenyama Minerals (Pty) Ltd v Genorah Resources (Pty) Ltd 20114 SA 113 (CC)

Chairperson, Standing Tender Committee v JFE Sapela Electronics (Pty) Ltd 20082 SA 638 (SCA)

Continental Illinois National Bank and Trust Co of Chicago v Greek Seamen's Pension Fund 19892 SA 515 (D)

Dalrymple v Colonial Treasurer 1910 TS 372 
De Reuck v Director of Public Prosecutions, Witwatersrand Local Division 20026 SA 370 (W)

Eskom Holdings Ltd v New Reclamation Group (Pty) Ltd 20094 SA 628 (SCA)

Ferreira v Levin; Vryenhoek v Powell 19961 SA 984 (CC)

FirstRand Bank Ltd v Chaucer Publications (Pty) Ltd 20082 SA 592 (C)

Freedom Under Law v Acting Chairperson: Judicial Service Commission 20113 SA 549 (CC)

Giant Concerts CC v Rinaldo Investments (Pty) Ltd 20133 BCLR 251 (CC) Jacobs $v$ Waks 19921 SA 521 (A)

Kruger v President of Republic of South Africa 20091 SA 417 (CC)

Lawyers for Human Rights v Minister of Home Affairs 20044 SA 125 (CC)

Minister of Home Affairs $v$ Eisenberg \& Associates: In re Eisenberg \& Associates Minister of Home Affairs 20035 SA 281 (CC)

Mistry v Interim Medical and Dental Council of South Africa 19984 SA 1127 (CC)

Moseme Road Construction CC v King Civil Engineering Contractors (Pty) Ltd 20104 SA 539 (SCA)

Oudekraal Estates (Pty) Ltd v City of Cape Town 20101 SA 333 (SCA)

S v Zuma 19952 SA 642 (CC)

Savoi v National Director of Public Prosecutions 20145 SA 317 (CC)

Secureco (Pty) Ltd $v$ Ethekwini Municipality (KZD) (unreported) case number $1100 / 2015$ of 1 April 2016

Steenkamp v Provincial Tender Board, Eastern Cape 20073 SA 121 (CC)

Trencon Construction (Pty) Ltd $v$ Industrial Development Corporation of Southern Africa Ltd 20155 SA 245 (CC) 
Tulip Diamonds FZE v Minister of Justice and Constitutional Development 20132 SACR 443 (CC)

Waikiwi Shipping Co Ltd v Thomas Barlow and Sons (Natal) Ltd 19781 SA $671(\mathrm{~A})$

Westinghouse Electric Belgium SA v Eskom Holdings SOC Ltd (GJ) (unreported) case number 2014/35650 of 2 April 2015

Westinghouse Electric Belgium SA v Eskom Holdings SOC Ltd 20163 SA 1 (SCA)

Wildlife Society of Southern Africa $v$ Minister of Environmental Affairs and Tourism of the Republic of South Africa 19963 SA 1095 (TkS)

Wolgroeiers Afslaers (Edms) Bpk v Munisipaliteit van Kaapstad 19781 SA $13(\mathrm{~A})$

Wood v Ondangwana Tribal Authority 19752 SA 294 (A)

\section{Legislation}

Constitution of the Republic of South Africa Act 200 of 1993

Constitution of the Republic of South Africa, 1996

Promotion of Administrative Justice Act 3 of 2000

\section{List of Abbreviations}

$\begin{array}{ll}\text { CCR } & \text { Constitutional Court Review } \\ \text { PAJA } & \text { Promotion of Administrative Justice Act } 3 \text { of } \\ & 2000 \\ \text { SAJHR } & \text { South African Journal on Human Rights } \\ \text { SALJ } & \text { South African Law Journal } \\ \text { Stell LR } & \text { Stellenbosch Law Review }\end{array}$

